\title{
REVIEW
}

\section{Molecular Mechanisms in Chronic Obstructive Pulmonary Disease}

\author{
Potential Targets for Therapy \\ Willem I. de Boer, ${ }^{1,}$ Vijay K.T. Alagappan, ${ }^{2}$ and Hari S. Sharma ${ }^{2}$ \\ ${ }^{1}$ Netherlands Asthma Foundation, Leusden and ${ }^{2}$ Cardiopulmonary Molecular Biology Lab, \\ Dept. of Pharmacology, Erasmus MC, University Medical Center, Rotterdam, The Netherlands
}

\begin{abstract}
Chronic obstructive pulmonary disease (COPD) is a chronic inflammatory lung disease associated with progressive airflow obstruction. Tobacco smoking is the main risk factor worldwide. In contrast to asthma, antiinflammatory therapies are rather ineffective in improving chronic symptoms and reducing inflammation, lung function decline, and airway remodeling. Specific drugs that are directed against the remodeling and chronic inflammation, thereby preventing lung tissue damage and progressive lung function decline, must be developed. Experimental models and expression studies suggest that anti-vascular endothelial growth factor (VEGF) receptor strategies may be of use in patients with emphysema, whereas anti-HER1-directed strategies may be more useful in patients with pulmonary mucus hypersecretion, as seen in chronic bronchitis and asthma.

Growth factors and cytokines including VEGF, fibroblast growth factors, transforming growth factor- $\beta$, tumor necrosis factor- $\alpha$, CXCL1, CXCL8, and CCL2, and signal transduction proteins such as mitogen-activated protein kinase $\mathrm{p} 38$ and nuclear factor- $\mathrm{\kappa B}$, seem to be important pathogenetic molecules in COPD. Specific antagonists for these proteins may be effective for different inflammatory diseases. However, their efficacy for COPD therapy has not yet been demonstrated. Finally, other drugs such as retinoic acids may provide restoration of lung tissue structure. Such approaches, however, must await the first results of growth factor or cytokine antagonist therapy in chronic lung diseases.
\end{abstract}

Index Entries: COPD, inflammation, airway remodelling, growth factors, cytokines, receptors, signal transduction, antagonists.

\section{INTRODUCTION}

Chronic obstructive pulmonary disease (COPD) is a chronic lung disease characterized by a progressive airflow limitation and associated with an abnormal inflammatory response of the lungs to noxious particles or gases $(1,2)$. COPD ranks among the top five leading causes of death worldwide and it is estimated that it will be in the mortality top three by 2020. Annual healthcare costs are greatly affected by COPD, being estimated at $2.8 \times 10^{8} £$ in The Netherlands (in 2000), $7.8 \times 10^{8} £$ in the United Kingdom (in 1996), and more than $14.5 \times 10^{9}$ US\$ direct costs in the United States (in 1993) (2).

\footnotetext{
*Author to whom all correspondence and reprint requests should be addressed. Tel: +31-33-4341245, Fax: +31-33-4341299. E-mail: deboer.pim@hetnet.nl
}

Tobacco smoking, the main risk factor, is associated with about $80 \%$ of COPD cases, and this includes passive smoking (3). Other risk factors include air pollution, the effects of indoor cooking, and asthma (2-4). However, only $15-20 \%$ of the smokers develop COPD, pointing to susceptibility factor(s) for COPD. Among these factors are genotype polymorphisms as exemplified by $\alpha 1$-antitrypsin (5) and other gene polymorphisms in molecules such as tumor necrosis factor (TNF)- $\alpha$, matrix metalloproteinase (MMP), or antioxidant genes (5-9) dependent on race and COPD phenotype (9).

\section{PATHOGENESIS OF COPD}

\section{Airway Remodeling}

COPD can be divided based on either clinical manifestations or pathological features into three different 
disorders: chronic bronchitis with airflow limitation, emphysema, and chronic bronchiolitis. COPD is characterized by a progressive lung function decline, measured as an increased annual decline in forced expiratory flow in $1 \mathrm{~s}\left(\mathrm{FEV}_{1}\right)(1,2)$. Research in the past two decades has shown pathological features of COPD patients comprising lung tissue remodeling-like changes in mucosal tissue fiber types and/or fibrosis, pulmonary and systemic inflammation, lung vascular remodeling, and declines in skeletal muscle mass and function (10-17). In emphysema, alveolar septs are deteriorated, resulting in reduced gas exchange and loss of elastic recoil of lung tissue (14). In chronic bronchitis with airflow limitation, bronchial gland enlargement and goblet cell hyperplasia leads to overproduction of mucus, resulting in mucoid airways obstruction (14). Often, COPD patients show a combination of these disorders. The pulmonary inflammation consists of neutrophils, macrophages, CD8+ T-cells (less prominent in severe COPD), mast cells, and eosinophils during exacerbations or in COPD patients showing reversible lung function $(16,18)$.

Pathophysiological features in addition to decreased lung function include chronic cough and dyspnoea. In smokers, epithelial cell metaplasia often occurs, whereas in chronic bronchitis, a goblet cell metaplasia is seen. Both types of metaplasia result in an impaired ciliary function. In chronic bronchitis, the hypersecreted mucus cannot be cleared sufficiently, resulting in chronic cough and dyspnoea. Although after cessation of smoking, the decline in lung function is reduced, lung function will not be restored and an increased airway resistance persists (19-20). This is probably due to pathological alterations in the airways like fibrosis and inflammation that reduce the diameter of airway lumen. In addition, after cessation of smoking an airway inflammation persists, hence contributing to the irreversibility of the decreased lung function $(10,12,16,18)$.

Other disturbed mechanisms are thought to include oxidative stress and protease-antiprotease balance $(12,16,18)$. This may be due to genetic predisposition such as polymorphisms reported for glutathion-S-transferase, epoxide hydrolase, MMPs 1, 9, or 12, and tissue inhibitor of metalloproteinase (TIMP) 2 (5-9,21). Alternatively, an imbalance is due to chronic exposition to cigarette smoke and subsequent release of free radicals and proteases such as elastase and MMPs from activated inflammatory cells. In turn, this may cause a chronic state of tissue damage, repair, and remodeling (14). Frequent exacerbations in COPD patients may eventually result in increased airway inflammation with eosinophils and neutrophils and higher levels of inflammatory mediators such as cytokines $(22,23)$.

\section{Role of Growth Factors}

Growth factors are small to large proteins that are divided in families based on their structural or functional homologies. The main families include the epidermal growth factor (EGF) family, transforming growth factor (TGF)- $\beta$ family, fibroblast growth factors (FGFs), insulin-like growth factor (IGF) family, plateletderived growth factor (PDGF) family, vascular endothelial growth factor (VEGF) family, and hepatocyte growth factor (HGF). This review will be confined to EGF-like growth factors, FGFs, VEGF, TGF- $\beta$, and specific cytokines. Growth factors are involved in a variety of processes including cellular proliferation, differentiation, migration, metabolism, and gene expression. Recently, localization of EGF-like growth factors in the human airways such as EGF, TGF- $\alpha$, heregulins, betacellulin, and heparin-binding EGF (HB-EGF) has been demonstrated (24). One of the receptors for EGF-like growth factors, HER1 (EGFR or c-erbB1), has been shown to be involved in mucus production in goblet cells either directly via stimulation by TGF- $\alpha$ or HBEGF, or indirectly via a variety of molecules including cytokines such as TNF- $\alpha$, interleukin (IL)- 4 or IL-13, cigarette smoke, or neutrophil-derived oxidants (25). In the airway epithelium of patients with asthma, expression of HER1, but not of the other HER or EGF family members, was enhanced as compared to healthy control subjects $(26,27)$. Increased expression of HER1 has been advocated for its involvement in epithelial repair and airway wall remodeling in asthma (27). In the airway epithelium of patients with COPD, expression of HER1, heregulin, and EGF was higher as compared to control subjects (24). In contrast, Vignola et al. (28) could not find any increased bronchial expression of EGF in chronic bronchitis patients, perhaps as a result of differences in the study population. The literature fully supports the notion that HER1 is involved in hypersecretion of mucus in chronic bronchitis as well as in neutrophilic inflammation, and eventually contributes to the pulmonary tissue remodeling seen in COPD and severe asthma. Also, EGF-like growth factors may also be involved in pulmonary tissue remodeling in COPD.

\section{FGF Family}

The FGF family consists of 23 members in man and their functional receptors are designated FGFR1 to FGFR5 (29). These FGFs are mitogenic factors involved in development, tissue homeostasis, and repair processes; FGF-1 and FGF-2 are also angiogenic factors (30-32). Among other growth factors, FGF-1, FGF-2, and FGF-7, as well as their receptors FGFR1 and FGFR2, are widely distributed in the human lung. In a recent study from our lab, differences in pulmonary expression of FGF-1, FGF-2, and FGFR1 were found between non- 
smokers and smokers with or without COPD $(15,32)$. With regard to FGF-2, airway expression is higher in bronchial tissue from asthmatics as compared to healthy control subjects (33). In COPD, expression levels of FGF1, FGF-2, and FGFR1 were observed to be increased in vascular and in epithelial compartments in lungs of patients with COPD as compared to subjects without COPD (15,32). FGF-1 can stimulate tissue remodeling by increasing collagenase expression and downregulation of collagen I expression in lung fibroblasts (30-32). It is yet unknown whether differences in FGF-7 expression patterns in lung tissue from patients with and without COPD or asthma exist. These data support a role for the FGF-FGFR axis in tissue remodeling in COPD.

\section{VEGF Family}

The VEGF family consists of seven members (VEGFA-F and placenta growth factor [PiGF]), which can bind to their respective cellular receptors VEGF receptor (VEGFR)-1 (also referred as Flt-1), VEGFR-2 (or KDR or Flk-1), and VEGFR-3 (or Flt-4). VEGF is predominantly known as a paracrine-acting, angiogenic factor stimulating mitogenesis, migration, and permeabilization of the vascular endothelium. Several studies support the idea that VEGF and its receptors contribute to tissue remodeling and disease severity in chronic lung diseases including asthma $(34,35)$. In patients with COPD, higher pulmonary VEGF expression was found in bronchial and alveolar epithelial in vascular smooth muscle as well as alveolar macrophages, whereas higher VEGFR-1 and VEGFR-2 expression was found in the endothelium as compared to patients without COPD (35). In this study, patients were not further stratified into emphysema severity classes. In patients with severe emphysema, VEGF expression in total lung extracts has been reported to be lower as compared to patients without COPD (36). Furthermore, VEGF levels in induced sputum were higher in patients with chronic bronchitis and airflow limitation, whereas they were lower in patients with emphysema as compared to healthy controls. In agreement with immunohistochemical data from our lab (35), VEGF sputum levels in patients with chronic bronchitis and airflow limitation were inversely correlated with $\mathrm{FEV}_{1}$ values (36). These data point at a COPD stage- and/or subtype-dependent expression of VEGF. This idea is supported by another study (37) demonstrating higher VEGF expression in lung tissue from patients with moderate COPD, but a lower expression in lung tissue from patients with severe emphysema as compared to subjects without COPD. Overexpression of VEGF in mice caused pulmonary emphysema, aberrant structure of capillary endothelium, and pulmonary inflammation with macrophages (38). Also, transgenic overexpression of
PiGF caused apoptosis of pneumocytes, emphysema, and a reduced endothelial cell number and VEGF expression (39). In contrast, adult mice in whom pulmonary VEGF expression was impaired by genetic targetting showed up to $86 \%$ lower VEGF levels as well as VEGFR-2 expression concomitant with alveolar and bronchial epithelial apoptosis, loss of elastic recoil, and airspace enlargement but no inflammation (40). Although inconclusive, these data from animal studies provided further support for a role of VEGFs and their receptors in tissue and vascular remodeling seen in COPD.

Assigning functional differences of VEGFRs in the pathogenesis of COPD can further support this. Activation of VEGFR2 is involved in angiogenesis by stimulating mitogenesis of endothelial cells during vascular damage-repair processes (41). In contrast, VEGFR1 is rather involved in stimulating vascular smooth muscle MMP activities and endothelial plasminogen activator and its inhibitor, activities needed for blood vessel maturation $(41,42)$. VEGFR-1 is also involved in inflammation, e.g., by stimulating migration of monocytes and CD34+ cells (43). Expression of VEGFR2 during repair is followed by VEGFR1 expression. As VEGFR1 has a higher affinity for VEGF than VEGFR2, it is thought that VEGFR1 is involved in the bronchial angiogenic process $(35,37,44)$. In COPD, pulmonary vascular expression of VEGF and VEGFR2 were reported to be increased in smokers with COPD or chronic bronchitis, whereas VEGFR1 expression did not differ between smokers with or without COPD (35). In addition, subjects with COPD showed an increased pulmonary vascular remodeling and thicker vessel walls (44). In contrast, in subjects with emphysema, pulmonary VEGF and VEGFR2 expression is lower as compared to subjects without COPD (45). Concomitant with the decreased expression, endothelial cell death and decreased endothelial proliferation occurred (45). Supporting evidence for the role of VEGFR2 in emphysema was provided in an animal model in which VEGFR2 was blocked, resulting in pulmonary endothelial cell apoptosis and emphysema (45).

Based on these data, we hypothesize that in COPD/ chronic bronchitis, the higher VEGF and VEGFR2 expression leads to an increased angiogenesis and vascular remodeling, which is inefficiently compensated by the low expression of VEGFR1. In subjects with COPD/ emphysema, VEGFR2 and VEGF expression are lower. Because VEGFR1 has a higher affinity for VEGF than VEGFR2, VEGFR1 scavenges VEGF from VEGFR2, resulting in specific VEGFR1 activation and in endothelial apoptosis, higher MMP activity, and vascular and alveolar destruction. Hence, the balance among VEGF, 
VEGFR1, and VEGFR2 is critical in the pathogenesis of COPD subtypes.

\section{TGF Family}

The TGF- $\beta$ subfamily has five members, of which TGF- $\beta 1-3$ have been shown to be present in mammals. TGF- $\beta$ shows a plethora of effects. It is known to act in a biphasic way on fibroblast proliferation, whereas it inhibits proliferation of other cells such as epithelial, endothelial, and smooth muscle cells. In addition, it stimulates (terminal) differentiation of several cell types, and enhances synthesis and secretion of extracellular matrix (ECM) proteins such as collagens. TGF- $\beta 1$ can drive wound repair by cellular migration and cell flattening toward wound closure, as well as restoration of tissue differentiation. A recent study pointed out that overexpression of TGF- $\beta 1$ in mice leads to Smad3dependent pulmonary expression of procollagens and antiproteinases as well as fibrosis (46). On the other hand, TGF- $\beta$ is chemotactic for monocytes/ macrophages and mast cells. Several studies provided evidence for an aberrant pulmonary expression of TGF- $\beta 1$ in patients with COPD. Pulmonary TGF- $\beta 1$ protein and mRNA expression was higher in lung tissue including airway epithelial cells of patients with mild to moderate COPD (47-49). The higher expression correlated with the increased number of macrophages in the airways (47), supporting a role for TGF- $\beta 1$ in the pathogenesis of COPD. Baraldo et al. (50) demonstrated that bronchial glands of patients with chronic bronchitis with airway obstruction have fewer cells showing a positive TGF$\beta R I I$ staining as compared with smokers without COPD. No differences between the patients groups were found with regard to the number TGF- $\beta 1$-positive cells. Thus, the literature supports the idea that the role of TGF- $\beta 1$ in COPD is dependent on the COPD subtype.

\section{AIRWAY SMOOTH MUSCLE AND ECM}

Focus is now on the bi-directional relationship between airway smooth muscle (ASM) cells and the ECM. Evidence is mounting that ASM cells can modulate ECM homeostasis as they express and release a variety of ECM proteins (51). Altered ECM deposition contributing to the airway wall remodeling is an important feature of chronic airway diseases such as asthma and COPD. We have demonstrated the increased bronchial deposition of ECM proteins, such as collagen I and III, fibronectin, and laminin as part of the airway remodeling process in patients with COPD (52). Staining for fibronectin was increased in bronchial blood vessels and for laminin in ASM as well as the microvasculature in patients with COPD as compared to controls (52). The synthetic capabilities of ASM cells in response to various mediators such as serum, TGF- $\beta$, and LTD 4 are documented by the fact that they can produce fibronectin, perlecan, elastin, laminin $\left(\alpha_{1}, \beta_{1}, \beta_{2}, \gamma_{2}\right)$, and various collagen subtypes (51-55). Under chronic inflammatory conditions, a number of cytokines and leukotrienes are produced in airways, which could directly act on ASM cells. In addition to their role in ECM deposition, ASM cells have been shown to have the capacity to produce MMPs $(54,55)$, which include the collagenases, gelatinases, stromelysins, elastases, and membrane-bound forms. MMPs are secreted in inactive form and are tightly regulated by TIMPs (56), thus eventually contributing to the alteration in ECM. ECM remains in a state of dynamic equilibrium of new synthesis and degradation controlled by the actions of MMPs and their tissue inhibitors (TIMPs). ASM contributes to this equilibrium by producing both ECM proteins (51) and MMPs and TIMPs (56), as well as growth factors such as TGF- $\beta 1$ (57) and connective tissue growth factor (CTGF) (58).

In turn, ECM proteins promote the survival, proliferation, cytokine synthesis, migration, and contraction of human ASM cells. There is accumulating evidence that ECM, in turn, alters a number of aspects of ASM biology through integrin signaling $(52,55)$. Thus, the intertwined relationship of ASM and ECM and their response to stimuli such as chronic inflammation in diseases like asthma and COPD contribute to the remodeling seen in airways of patients with these diseases.

\section{CYTOKINES AND CHEMOKINES}

Inflammatory cells of both the innate and the acquired immune system seem to play an important role in the pathophysiology of COPD $(14,16,18)$. In patients with COPD, higher numbers of macrophages and CD8+ T-cells were found in the airway walls and in vascular smooth muscle, whereas more neutrophils were observed in bronchial glands and the airway lumen $(16,18)$. Both cytokines and chemokines provide a chemotactic gradient and can activate these cells. Classical cytokines include ILs, interferons, and TNF- $\alpha$. Based on structural homology around four cysteine residues, chemokines can be subdivided into four subclasses, -C- , -CC- , -CXC- , and -CXXXC-, in which X substitutes for any amino acid. Two subclasses account for most of the chemokines: CXC $(\alpha)$ and CC $(\beta)$ chemokines (59). Cytokines and chemokines are synthesized by both structural cells (such as fibroblasts and epithelial, endothelial, and muscle cells) and inflammatory cells of the innate and the adaptive immune system. They act via specific membranebound receptors resulting in cell-specific reactions. With regard to COPD, protein and/or mRNA levels of 
Table 1

Expression and Polymorphisms of Growth Factors, Cytokines, and Chemokines in Chronic Obstructive Pulmonary Disease (COPD)

\begin{tabular}{|c|c|c|c|}
\hline Molecule & Product $^{a}$ & Compartment $^{b}$ & Data $^{c}$ \\
\hline EGF & Protein & Lung tissue & $\uparrow(\mathrm{CB})$ \\
\hline EGFR & Protein & Lung tissue & $\uparrow(\mathrm{COPD})^{d}$ \\
\hline HER3 & Protein & Lung tissue & $\uparrow(\mathrm{COPD})$ \\
\hline FGF-1 & Protein & Lung tissue & $\uparrow(\mathrm{COPD})$ \\
\hline FGF-2 & Protein & Lung tissue & $\uparrow(\mathrm{COPD})$ \\
\hline FGFR1 & Protein & Lung tissue & $\uparrow(\mathrm{COPD})$ \\
\hline \multirow[t]{2}{*}{ TGF- $\beta 1$} & Protein & Lung tissue & $\uparrow(\mathrm{COPD})$ \\
\hline & mRNA & Lung tissue & $\uparrow(\mathrm{COPD})$ \\
\hline \multirow[t]{4}{*}{ VEGF } & Protein & Lung tissue & $\downarrow$ (emphys) \\
\hline & & Lung tissue & $\uparrow(\mathrm{COPD})$ \\
\hline & Protein & $\mathrm{sp}$ & $\downarrow$ (emphys) \\
\hline & & $\mathrm{sp}$ & $\uparrow(\mathrm{COPD})$ \\
\hline VEGFR1 & Protein & Lung tissue & $\uparrow(\mathrm{COPD})$ \\
\hline \multirow[t]{2}{*}{ VEGFR2 } & Protein & Lung tissue & $\downarrow$ (emphys) \\
\hline & & & $\uparrow(\mathrm{COPD})$ \\
\hline \multirow[t]{3}{*}{ TNF- $\alpha$} & Protein & ser, sp, leg muscle & $\uparrow(\mathrm{COPD})$ \\
\hline & mRNA & ser, sp & $\uparrow(\mathrm{COPD})$ \\
\hline & Polymorph & Gene & yes (COPD) \\
\hline sTNFR p55 & Protein & $\mathrm{sp}^{e}$ & $\uparrow(\mathrm{COPD})$ \\
\hline sTNFR p75 & Protein & ser & $\uparrow(\mathrm{COPD})$ \\
\hline \multirow[t]{2}{*}{ CCL2 } & mRNA & Lung tissue & $\uparrow(\mathrm{COPD})$ \\
\hline & Protein & $\mathrm{sp}, \mathrm{BAL}$ & $\uparrow(\mathrm{COPD})$ \\
\hline \multirow[t]{2}{*}{ CCR2 } & mRNA & Lung tissue & $\uparrow(\mathrm{COPD})$ \\
\hline & Protein & Lung tissue & $\uparrow(\mathrm{COPD})$ \\
\hline CXCL1 & Protein & sp, Lung tissue & $\uparrow(\mathrm{COPD})$ \\
\hline \multirow[t]{3}{*}{ CXCL8 } & mRNA & Lung tissue & Higher \\
\hline & Protein & ser, sp, BAL & \\
\hline & & Lung tissue & Higher \\
\hline \multirow[t]{2}{*}{ CXCR2 } & Protein & PBL & Higher \\
\hline & mRNA & BAL cells & Higher \\
\hline
\end{tabular}

aPolymorph, polymorphism; no., number; epi, bronchial epithelial.

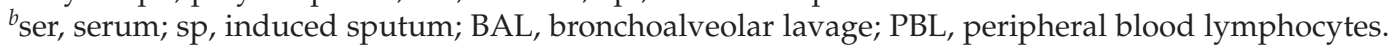

${ }^{c}$ Expression or levels in COPD as compared to controls; yes, polymorphisms reported; $\mathrm{CB}$, chronic bronchitis; emphys, severe emphysema.

${ }^{d}$ Ex-smokers with COPD.

${ }^{e}$ Inverse correlation with $\mathrm{FEV}_{1}$. Data were obtained from references $(15,16,24,28,35-37,47,48,59$, $60,72)$.

different cytokines and chemokines have been found to be altered compared with subjects without COPD (Table 1). Among these, TNF- $\alpha$ or TNF- $\alpha$ receptor (TNFR) levels, soluble IL-1 receptor antagonist (sIL1Ra), CCL2 (or monocyte chemoattractant protein [MCP]-1) and its receptor CCR2, CCL3 (or macrophage inflammatory protein [MIP]-1 $\alpha$ ), and CCL4 (or MIP-1 $\beta$ ) and their receptor CCR5, CXCL8, (or IL-8), and CXCL10 (or interferon-inducible protein [IP]-10) can be discerned as pro-inflammatory factors. In Fig. 1, a brief outline of the proposed remodeling and inflammatory mechanism in COPD is provided $(18,59)$. Based on this, specific anti-inflammatory therapies are being developed for COPD (60). In addition to the inflammatory 


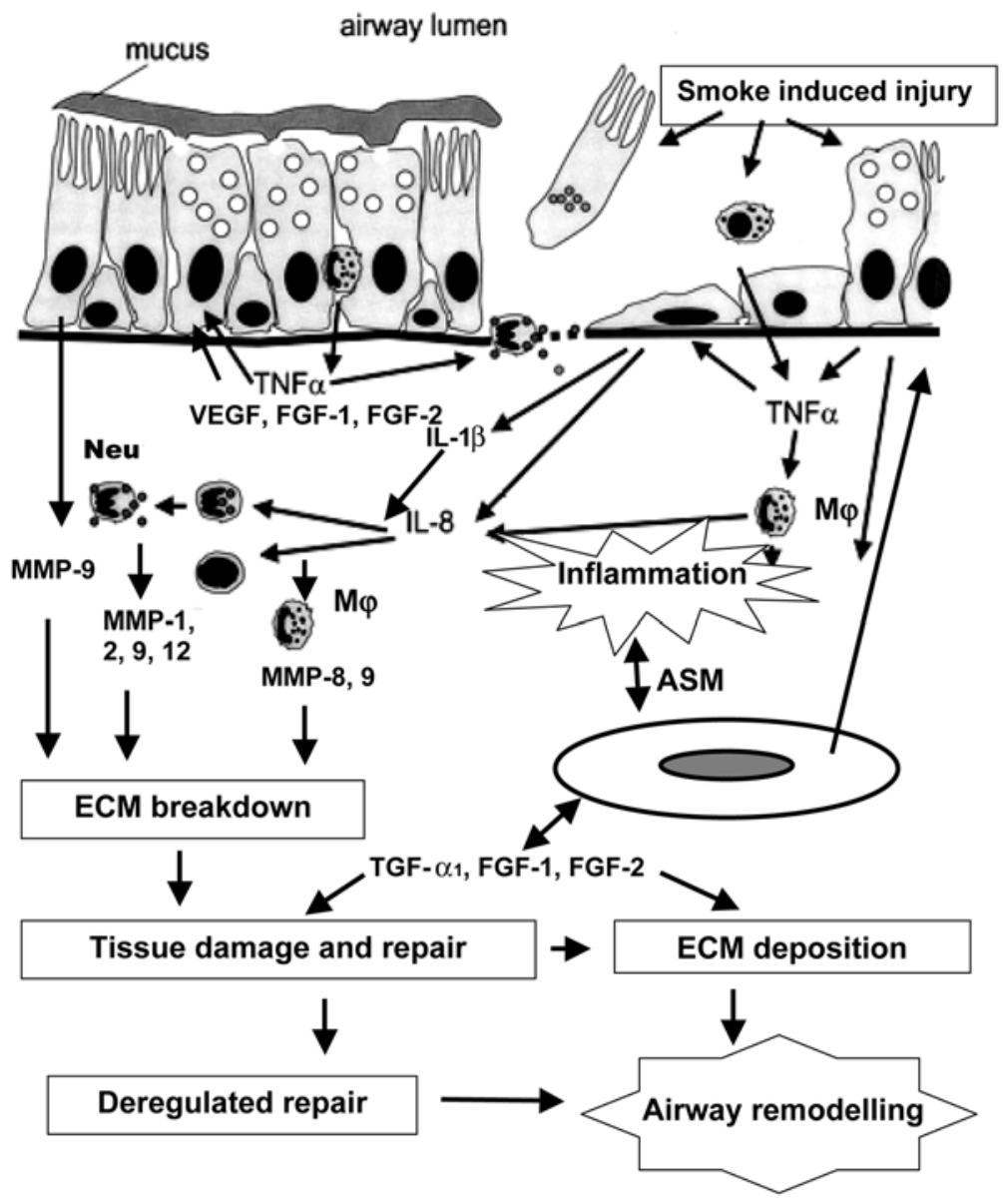

Fig. 1. Simplified scheme of cytokine and growth factor actions in human airways. On triggering, e.g., with tobacco smoke, epithelial cells are damaged, epithelial cells and resident macrophages produce inflammatory mediators such as tumor necrosis factor (TNF)- $\alpha$, interleukin (IL)-1 $\beta$, and IL-8. In turn, inflammatory mediators-stimulate migration of monocytes/macrophages, neutrophils, and CD8+ T-lymphocytes to the airway. Both TNF- $\alpha$ and IL- 8 can cause degranulation of neutrophils with production and release of serine-proteinases and matrix metalloproteinases (MMPs) as well as free radicals that can cause matrix and epithelial damage. In turn, TNF- $\alpha$ and released growth factors such as vascular endothelial growth factor (VEGF) and fibroblast growth factor (FGF)-1 and -2 orchestrate epithelial repair. Ongoing inflammation and tissue breakdown trigger the release of growth factors such as transforming growth factor (TGF)- $\beta 1$, inducing extracellular matrix (ECM) production by myofibroblasts. Repetitive tissue damage and repair can lead to excessive ECM deposition and subepithelial fibrosis. Neu, neutrophil; $\mathrm{M} \varphi$, macrophage; T, CD8+ T-lymphocytes.

effects, recent studies provided more evidence that cytokines and chemokines are also involved in tissue remodeling.

Several studies have shown that epithelial cells express the CXCL8 receptor CXCR2 suggesting a role for CXCL8/CXCR2 in wound repair (18). In vivo, impaired CXCR2 expression in mice resulted in delayed skin wound repair as compared to wild-type mice, which could not be restored by exogenous CXCL8 application (61). Alternatively, topical application of CXCL1 or CXCL8 stimulated human skin wound repair in chimeric mice (62). The role of CXCL8 in wound repair was further substantiated by in vitro experiments. These data support a direct role for CXCL8 in repair of epithelial injury often seen in airway epithelium in COPD (18).

CCL2 and CCL3 are produced by a variety of cells including macrophages and endothelial and epithelial cells. Wound healing studies in mice and man demonstrated that CCL2 and CCL3 expression are enhanced during repair of injured skin (63) or skeletal muscle in a time-dependent manner and coinciding with macrophage influx. TNF- $\alpha$ seems to be involved in the regulation of CCL2 expression, as TNF- $\alpha$ scavenging with a TNF- $\alpha$ antibody reduced CCL2 levels during wound repair (63).

In vitro, CCL2 and its receptor, CCR2, were demonstrated to be directly involved in endothelial and lung 
epithelial cell proliferation and migration and wound closure $(18,64,65)$. In addition, CCL2 was found to stimulate collagen synthesis in rat lung fibroblasts via a TGF- $\beta 1$-dependent pathway, hence potentially contributing to a fibrogenetic remodeling as seen in COPD (66). In turn, TGF- $\beta 1$ was reported to induce CCL2 protein levels via downstream intracellular mechanisms including reactive oxygen species, mitogen-activated protein kinase (MAPK) p38, and p42/44 in mesangial cells (67). Hence the CCL2-TGF- $\beta$ axis may potentially contribute to fibrogenetic remodeling as seen in COPD.

\section{CURRENT THERAPY FOR COPD}

Current therapies for COPD are predominantly based on anti-inflammatory drugs for treating asthma. These include corticosteroids or theophylline with or without bronchodilators, including $\beta_{2}$-agonists $(1,68)$. Upon treatment with corticosteroids, some studies reported reduction of the number of exacerbations and improved quality of life assessed with $\mathrm{FEV}_{1}$ values after short- or long-term treatment (69), or no effect on lung function. However, steroid treatment in COPD is rather ineffective in reducing airway inflammation and the decline in lung function, in contrast to steroid treatment in patients with asthma and COPD with bronchial hyperresponsiveness and eosinophilia. Furthermore, side effects of steroids include increased risk of hip fractures, skin bruising, and candidiasis, and the airway remodeling is not positively affected by the current treatment.

Novel possible broad-acting inhibitors of inflammation include specific inhibitors of phosphodiesterase 4 (PDE4), leukotriene receptor antagonists, inhibitors of 5-lipoxygenase (leukotriene synthesis inhibitor), and cyclo-oxygenase (COX) inhibitors (which inhibit prostaglandin synthesis) $(70,71)$. However, more specific therapies directed against inflammation and remodeling without adverse effects are needed. Antiinflammatory cytokine antagonists seem useful in several Th1- cytokine-driven diseases, such as rheumatoid arthritis (RA), psoriasis, and inflammatory bowel disease or Crohn's disease. Inhibitors of remodeling include antagonists for growth factors such as TGF- $\beta$ and VEGF, and inhibitors of MMPs. This part of the review focuses on the recent developments in this field.

\section{POTENTIAL DRUGS: GROWTH FACTOR OR CYTOKINE ANTAGONIST DRUGS}

Different intervention levels can be explored. Currently examined levels of intervention include (1) scavenging and neutralization of proteins by binding to soluble receptors or neutralizing antibodies; (2) inhibition of protein binding to its receptor by small com- pounds or incomplete and nonactivating cytokines; (3) inhibition of protein activation (processing of preprotein into mature protein); and (4) inhibition of signal transduction and transcription via inhibition of receptordependent tyrosine kinases, MAPKs, or nuclear factor

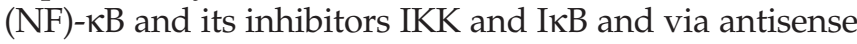
mRNA or small interfering (si)RNA molecules for growth factors or cytokines. Many potential drugs are still in preclinical development or in clinical trial phases for diseases other than COPD (Tables 2 and 3). A few are, however, in clinical trials, with little information on them having been published for COPD in peer-reviewed journals. General adverse effects of injected drugs include reactions around the site of administration and, less frequently, a delayed hypersensitivity-like reaction and new onset of autoimmunity; on rare occasions, drug-induced systemic lupus erythematosis and demyelination, serious infections, vasculitis, or malignancies can occur $(59,60)$. This may lead to a loss of efficacy. In the following sections, some potential drugs are highlighted.

\section{EGFR/HER}

Little has been published on the expression of EGFlike growth factors and HER1-family members in COPD. A few studies reported a higher expression of HER1, EGF or heregulin in airway epithelium in patients with chronic bronchitis or COPD $(24,28,72)$. A recent study also demonstrated a higher bronchial epithelial expression of HER3 in patients with COPD as compared with smokers without COPD and healthy subjects (72). Several studies pointed to the involvement of HER1 in mucus overproduction and goblet cell metaplasia. This supports a potential targeting of these molecules for treatment of tissue remodeling in COPD. Among the antagonists of HER1 or HER2-4 as well as inhibitors of their ligands are antibodies directed against the ligand-binding site such as cetuximab and h$\mathrm{R} 3$, or small molecules directed against the tyrosine kinase domain such as gefitinib or trastuzumab. Several of these antagonists are already in clinical phase studies or are already approved by the Food and Drug Administration (FDA) for treatment of specific cancers (cetuximab, erlotinib, trastuzumab, gefitinib) (Table 2).

Cetuximab is a chimeric immunoglobulin (Ig)G1 antibody binding to the extracellular domain of HER1, blocking ligand binding. Although approved by the FDA for use in metastatic colon cancer, it is in clinical trial for different carcinomas. One of the adverse effects is the development of interstitial lung disease, which is not favorable for patients with COPD. Another antagonist against the extracellular domain of HER1 is h-R3, a humanized antibody IgG1. It inhibits proliferation of carcinoma cells both in vitro and in vivo and VEGF expression, angiogenesis, 
Table 2

Examples of Antagonists in Clinical Trial: Potentially Useful Drugs

for the Treatment of Chronic Obstructive Pulmonary Disease (COPD)

\begin{tabular}{|c|c|c|c|}
\hline Name & Type of compound & Function & Trial phase (disease) \\
\hline \multicolumn{4}{|l|}{ EGFR/HER2 } \\
\hline \multirow{2}{*}{$\begin{array}{l}\text { Cetuximab } \\
\quad \text { (IMC-225; Erbitux) }\end{array}$} & Chimeric IgG1 human/mouse & blocking ligand & ${ }^{1}(\mathrm{CC})$ \\
\hline & $\begin{array}{l}\text { Antibody binding to extracellular } \\
\text { domain of EGFR }\end{array}$ & binding & \\
\hline h-R3 & $\begin{array}{l}\text { Humanized IgG1 antibody binding } \\
\text { to extracellular domain of EGFR }\end{array}$ & blocking, ligand binding & IIlb (HNC) \\
\hline ABX-EGF & $\begin{array}{l}\text { Human IgG2 monoclonal antibody } \\
\text { against human EGFR }\end{array}$ & $\begin{array}{l}\text { blocking ligand } \\
\text { binding }\end{array}$ & II (RCC) \\
\hline $\begin{array}{l}\text { Erlotinib } \\
\text { (Tarceva; OSI-774) }\end{array}$ & Oral 4-anilinoquinazoline & $\begin{array}{l}\text { inhibiting EGFR } \\
\text { tyrosine kinase }\end{array}$ & ${ }^{1}(\mathrm{NSCLC})$ \\
\hline $\begin{array}{l}\text { Gefitinib } \\
\quad \text { (Iressa; ZD1839) }\end{array}$ & Oral 4-anilinoquinazoline & $\begin{array}{l}\text { inhibiting EGFR } \\
\text { tyrosine kinase }\end{array}$ & ${ }^{1}$ (NSCLC) \\
\hline $\begin{array}{l}\text { Lapatinib } \\
\quad(\text { GW572016) }\end{array}$ & Small molecule inhibitor & $\begin{array}{l}\text { inhibiting EGFR \& HER2 } \\
\text { tyrosine kinase }\end{array}$ & III (BC; cancer) \\
\hline PKI166 & Oral pyrrolo-pyrimidine derivate & $\begin{array}{l}\text { inhibiting EGFR\& HER2 } \\
\text { tyrosine kinase }\end{array}$ & II (ST) \\
\hline $\begin{array}{l}\text { Canertinib } \\
\text { (CI1033;PD 183805) }\end{array}$ & 4-Anilinoquinazoline derivate & $\begin{array}{l}\text { inhibiting pan-HER } \\
\text { tyrosine kinase }\end{array}$ & $\mathrm{I}(\mathrm{BC})$ \\
\hline \multicolumn{4}{|l|}{ TNF- $\alpha$} \\
\hline Infliximab & $\begin{array}{l}\text { Chimeric IgG1 human/mouse } \\
\text { anti-TNF- } \alpha \text { antibody }\end{array}$ & $\begin{array}{l}\text { Neutralization } \\
\text { TNF- } \alpha\end{array}$ & $\begin{array}{l}\text { 1(RA;CD) (Remicade) } \\
\text { III (AS; psoriasis); } \\
\text { II (COPD; asthma) }\end{array}$ \\
\hline \multirow{2}{*}{$\begin{array}{l}\text { Etanercept } \\
\quad \text { (Enbrel) } \\
\text { Adalimumab } \\
\quad(\text { Humira })\end{array}$} & $\begin{array}{l}\text { Human TNFR p75 :Fc IgG1 } \\
\text { fusion protein }\end{array}$ & $\begin{array}{l}\text { Neutralization } \\
\text { TNF- } \alpha\end{array}$ & $\begin{array}{l}\text { (RA;AS); } \\
\quad \text { II (asthma) }\end{array}$ \\
\hline & $\begin{array}{l}\text { Human IgG1 anti-TNF- } \alpha \\
\text { antibody }\end{array}$ & $\begin{array}{l}\text { Neutralization } \\
\text { TNF- } \alpha\end{array}$ & $\begin{array}{l}\text { 1(RA); } \\
\text { III (AS;CD); } \\
\text { II (psoriasis) }\end{array}$ \\
\hline $\begin{array}{l}\text { Afelimomab } \\
\quad(\text { Segard })\end{array}$ & $\begin{array}{l}\text { Mouse } F\left(a^{\prime}\right) 2 \text { anti- } \\
\text { TNF- } \alpha \text { fragment }\end{array}$ & $\begin{array}{l}\text { Neutralization } \\
\text { TNF- } \alpha\end{array}$ & III (sepsis) \\
\hline $\begin{array}{l}\text { CDP-571 } \\
\text { (Humicade) }\end{array}$ & $\begin{array}{l}\text { Humanised mouse } \\
\text { anti-TNF- } \alpha \text { antibody }\end{array}$ & $\begin{array}{l}\text { Neutralization } \\
\text { TNF- } \alpha\end{array}$ & III (CD) \\
\hline CDP-870 & $\begin{array}{l}\text { Polyethylene-glycolated-human } \\
\text { F(ab') anti-TNF- } \alpha \text { fragment }\end{array}$ & $\begin{array}{l}\text { Neutralization } \\
\text { TNF- } \alpha\end{array}$ & III (RA;CD) \\
\hline Onercept & Rec. human sTNFR p55 & $\begin{array}{l}\text { Neutralization } \\
\text { TNF- } \alpha\end{array}$ & II (CD; psoriasis) \\
\hline PEG sTNF-RI & $\begin{array}{l}\text { Polyethylene-glycolated-human } \\
\text { rec. soluble TNF- receptor p55 }\end{array}$ & $\begin{array}{l}\text { Neutralization } \\
\text { TNF- } \alpha\end{array}$ & II (RA) \\
\hline CytoTab & $\begin{array}{l}\text { Sheep } F\left(a b^{\prime}\right) \text { anti-TNF- } \alpha \\
\text { antibody }\end{array}$ & $\begin{array}{l}\text { Neutralization } \\
\text { TNF- } \alpha\end{array}$ & $\begin{array}{l}\text { IIlb (sepsis); } \\
\text { I (CD) }\end{array}$ \\
\hline ISIS-104838 & $\begin{array}{l}\text { Antisense TNF- } \alpha \\
\text { methoxy-oligonucleotide }\end{array}$ & $\begin{array}{l}\text { Inhibition TNF- } \alpha \\
\text { transcription }\end{array}$ & II (RA;CD) \\
\hline BMS-561392 & $\begin{array}{l}\text { TACE \& MMP } \\
\text { Inhibitor }\end{array}$ & $\begin{array}{l}\text { Blocks pre-TNF- } \alpha \\
\text { processing }\end{array}$ & II (RA;CD) \\
\hline Marimastat & $\begin{array}{l}\text { TACE \& MMP } \\
\text { Inhibitor }\end{array}$ & $\begin{array}{l}\text { Blocks pre-TNF- } \alpha \\
\text { processing }\end{array}$ & III (cancer) \\
\hline \multicolumn{4}{|l|}{ CCL2/CCR2 } \\
\hline MLN-1202 & $\begin{array}{l}\text { humanized mouse } \\
\text { anti CCR2 antibody }\end{array}$ & $\begin{array}{l}\text { Inhibits binding } \\
\text { CCL2 to CCR2 }\end{array}$ & II (RA) \\
\hline
\end{tabular}


Table 2 (continued)

\begin{tabular}{|c|c|c|c|}
\hline Name & Type of compound & Function & Trial phase (disease) \\
\hline INCB3284 & CCR2 antagonist & $\begin{array}{l}\text { Inhibits binding } \\
\text { CCL2 to CCR2 }\end{array}$ & I (DTH, RA) \\
\hline RS-504393 & spiropiperidine & $\begin{array}{l}\text { Inhibits binding } \\
\text { CCL2 to CCR2 }\end{array}$ & Preclinical \\
\hline $\mathrm{MCP}-1_{(9-76)}$ & $\begin{array}{l}\text { CCL2 peptide equal to } \\
\text { amino acids } 9 \text { to } 76\end{array}$ & $\begin{array}{l}\text { Inhibits binding } \\
\text { CCL2 to CCR2 }\end{array}$ & Preclinical \\
\hline \multicolumn{4}{|l|}{ CXCR2 } \\
\hline SB332235 & CXCR2 antagonist & $\begin{array}{l}\text { Inhibits binding } \\
\text { CXCL8 to CXCR2 }\end{array}$ & I (COPD) \\
\hline SB656933 & CXCR2 antagonist & $\begin{array}{l}\text { Inhibits binding } \\
\text { CXCL1 to CXCR2 }\end{array}$ & I (COPD) \\
\hline SB265610 & biphenolic urea derivate & $\begin{array}{l}\text { Inhibits CXCL1/8 } \\
\text { to CXCR2 }\end{array}$ & Preclinical \\
\hline SB225002 & biphenolic urea derivate & $\begin{array}{l}\text { Inhibits CXCL1/8 } \\
\text { to CXCR2 }\end{array}$ & Preclinical \\
\hline $\mathrm{GROa}_{[8 \tilde{n} 73)}$ & $\begin{array}{l}\text { CXCL1 peptide equal to } \\
\text { amino acids } 8 \text { to } 73\end{array}$ & $\begin{array}{l}\text { Inhibits CXCL1 } \\
\text { binding to CXCR2 }\end{array}$ & Preclinical \\
\hline
\end{tabular}

AS, ankylosing spondylitis; BC, breast tumours; CC, colon cancer; CD, Crohn's disease; HNC, head and neck cancer; DTH, delayed type hypersensitivity; HIV, human immunodeficiency virus; MS, multiple sclerosis; NSCLC, non-small-cell lung cancer; RA, rheumatoid arthritis; RCC, renal cell cancer; ST, solid tumors; ${ }^{1}$, approved by the US Food and Drug Administration (FDA).

and tumorigenesis in mice and man (73). In contrast to the small-molecule HER1 inhibitor ZD1839, h-R3 does not stimulate epithelial apoptosis (73). Potentially, this drug may reduce goblet cell hyperplasia as seen in smokers with COPD, or vascular remodeling or angiogenesis as can be observed in patients with emphysema. Trastuzumab (Herceptin) is a recombinant humanized murine anti-HER2 monoclonal antibody. It is approved by the FDA for treatment of metastatic breast carcinoma. It induces HER2 receptor downmodulation, inhibits critical signaling pathways (i.e., Ras-Raf-MAPK and PI3K/Akt), blocks cell cycle progression by inducing the formation of p27/Cdk2 complexes, and inhibits HER2 cleavage and angiogenesis (74). 2C4 is a humanized monoclonal antibody targeting the role of HER2 as a co-receptor by sterically hindering HER2 recruitment in heterodimers with other HER receptors (74).

Among the small molecules against HER1 is gefitinib (Iressa; ZD1839). This is a 4-anilinoquinazoline targetting the ATP-binding site in the intracellular tyrosine phosphorylation site of growth factor receptors including HER1 and HER2 (75). It has been approved by the FDA for use in local or metastatic non-small-cell lung carcinoma (NSCLC). Although capable of reducing tumor growth, it stimulates caspase-dependent apoptosis of lung epithelial cells in vitro (76). This is an effect that is not favorable in case of emphysema, in which alveolar epithelial cells are being lost presumably via apoptosis. PKI166 is an oral pyrrolo-pyrimidine derivate inhibiting HER1 and HER2 tyrosine kinase activity. PKI166 is capable of reducing tumor growth but also stimulates epithelial intercellular adhesion and inhibits angiogenesis associated with an impaired VEGF and CXCL8 expression as well as endothelial apoptosis in human carcinoma growing in mice (77). Especially the re-establishment of epithelial adhesion, reduction of CXCL8 expression, and inhibition of angiogenesis may be favorable in treatment of patients with COPD, potentially leading to intact airway epithelium, reduced neutrophilic inflammation, and less vascular remodeling.

The water-soluble, orally available 4-anilinoquinazoline canertinib (CI-1033) is a specific pan-HER1-4 tyrosine kinase inhibitor, thereby potentially impairing HER functioning. All of these compounds may reduce excessive proliferation and mucin synthesis as seen in chronic bronchitis. On the other hand, further epithelial and endothelial apoptosis, as seen with trastuzumab, should be avoided in patients with emphysema. However, no data have yet been published on its efficacy for reducing tissue remodeling in the treatment of nononcological disorders.

\section{VEGF AND VEGFR, FGF AND FGFR.}

Several studies have pointed to the involvement of VEGF/VEGFR in pulmonary and vascular remodeling and inflammation. VEGF transgenic mice showed alveolar vascular and airspace remodeling as well as 
increased numbers of alveolar macrophages, or a Th2type airway inflammation in a murine asthma model (78). An in vitro study demonstrated that VEGF induced monocyte migration via VEGFR1 expressed by monocytes $(78,79)$. Therefore, such inhibitors may be of potential use for treatment of vascularization, as seen in asthma or in specific subtypes of COPD, such as chronic bronchitis, but not emphysema. Several drugs have been developed to reduce tumor growth and metastasis by impairing the neovascularization. Antagonists include those in clinical trials and in preclinical investigations. Among those in clinical trial are VEGF-Trap, bevacizumab (or: Avastin), CEP-7055, VEGF Trap, and PTK787 (79).

Avastin is a humanized monoclonal IgG1 antibody against VEGF preventing binding of VEGF to VEGFR1 and VEGFR2. The FDA has approved it for intravenous treatment of metastatic colon and rectal cancer. Clinical studies have pointed out that this antibody has little clinical activity as a single drug, but in combination with chemotherapy in the treatment of a variety of cancers, it reduced tumor growth and angiogenesis (80). Side effects of Avastin were noted to include thrombosis and hypertension and, in combination with chemotherapy, cerebrovascular and cardiovascular infarctions (80). CEP-7055 is a small-molecule, water-soluble indenopyrrolocarbazole derivate inhibitor of pan-VEGFR tyrosine kinase activity. CEP-7055 is reported to inhibit pulmonary VEGFR2 activation in mice, capillary formation by human and rat endothelial cells in vitro and in vivo in mice, granuloma formation and vascularization in a chronic inflammation model in mice, and tumorigenesis $(80,81)$. It is currently being evaluated in phase-I trials for treating patients with solid tumors. VEGF Trap is a soluble VEGFR constructed from VEGFR1- and VEGFR2binding domains linked to an IgG1 constant region. Different in vivo mouse models demonstrated that VEGF Trap reduced hemangiogenesis, lymphangiogenesis, and tumor growth and size (81). VEGF Trap entered clinical trial phase-I studies for treatment of solid tumors. However, little is known yet of side effects or its efficacy in treatment of chronic inflammatory diseases.

SU6668 is a IgG2a fusion protein inhibiting tyrosine kinase activity of FGFR1, VEGFR2, and platelet growth factor receptor b. SU6668 was demonstrated to inhibit tumor growth, lung cancer metastasis, and tumor vascularization (82). Its broader spectrum of inhibitory effects may be more effective in treating airway remodeling in COPD. Many other small-molecule VEGFR inhibitors are being developed for clinical therapy $(38,82)$. Despite these data, nothing has been published yet on such treatments in asthma or COPD. Also, the redundancy of the VEGF-VEGFR system may temper applicability and efficacy of VEGF/VEGFR inhibitors (83). In addition, in, e.g., patients with emphysema, inhibitors of apoptosis are needed whereas in contrast to chronic bronchitis, expression of hypoxia-inducible factor, VEGF, and VEGFR2 may be stimulated to overcome endothelial and epithelial cell death and improve vascular restoration (84). Hence, treatment with VEGF/VEGFR inhibitors should be further investigated and may be restricted to specific subtypes of chronic lung diseases.

\section{TGF-B AND TGF-BR}

Both pulmonary TGF- $\beta 1$ and FGFR1 expression have been reported to be enhanced in COPD as compared to smokers without COPD. The expression patterns were reported to be related to either inflammation or tissue remodeling $(15,32,47)$. One of the involved mechanisms may include TGF- $\beta 1$, which can induce FGFR1 and FGFR2, but not HER1, expression in human lung fibroblasts in vitro (85). The enhanced expression of TGF- $\beta 1$ or TGF- $\beta$-mediated pathways may hence be a target for therapeutic intervention.

A few inhibitors have been reported to reduce TGF $\beta_{1}$ expression, scavenge TGF $\beta$, interfere with binding of TGF $\beta$ to its receptors, or to inhibit TGF $\beta R$ signal transduction. All of these antagonists are still in preclinical development. The adenoviral 5 vector encoding for TGF- $\beta 1$ antisense RNA molecules was reported to reduce TGF- $\beta 1$ expression, leading to impaired collagen and smooth muscle cell actin in liver cells in mice (86). The recombinant TGF- $\beta 1$ peptide coding for amino acids 41 to 65 antagonizes TGF- $\beta 1$ binding to its receptor. The peptide stimulated re-epithelialization of skin wounds in mice with concomitant reduction of wound contraction and scarring (87). As lung epithelial damage is often seen in smokers with or without COPD, and epithelial TGF- $\beta 1$ expression is higher in airway epithelium in

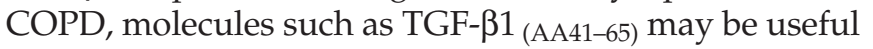
in epithelial repair. Soluble TGF- $\beta$ receptor molecules TGF- $\beta$ RII and TGF- $\beta$ RIII were shown to reduce mammary tumor metastases or airway fibrosis while TGF- $\beta$ function in normal tissues remained intact $(87,88)$. However, Lutgens et al. (89) found that sTGF- $\beta$ RII reduced fibrosis in an artherosclerosis mouse model while increasing T-cell inflammation. As patients with COPD also show higher numbers of T-cells, modulating TGF- $\beta$ RII functioning may have adverse effects in patients with COPD.

\section{CYTOKINES}

As pointed out previously, cytokines and chemokines are not only involved in innate and acquired immunity processes but also may be involved in tissue remodeling in chronic lung diseases like COPD. We recently reviewed 
potential antagonists regarding cytokine therapy for COPD patients summarized a plethora of molecules (60). Important potential targets for therapy include TNF- $\alpha$, CCL2, CXCL1, and CXCL8 and their respective receptors. This section outlines drugs that may be potential for therapy of patients with COPD.

The pro-inflammatory cytokine TNF- $\alpha$ activates and stimulates migration of monocytes, macrophages, neutrophils, and T-cells. Higher levels of TNF- $\alpha$ have been observed in induced sputum and plasma in patients with COPD (Table 1). Studies on gene-activating polymorphisms suggested that TNF- $\alpha$ polymorphisms rely on different populations (e.g., Japanese vs Caucasian) and the location (e.g., -376G/A, -308, -238G/A, +489G/A) (6,90). However, polymorphisms seem to be associated with a poorer prognosis (90). TNF- $\alpha$ was shown to play a role in cigarette smoke-induced emphysema and airway inflammation with neutrophils and macrophages in mice (91). In addition, following exposure to cigarette smoke, TNFR p55- and p75-deficient mice had threefold less increase in airspace enlargement, $65 \%$ fewer neutrophils, and no increase in macrophage numbers in the bronchoalveolar lavage (BAL) fluid as compared with wild-type mice (92).

Drugs aimed at reducing TNF- $\alpha$ levels have been developed for treating chronic diseases such as rheumatoid arthritis, psoriasis, and inflammatory bowel disease (especially Crohn's disease) (Table 2). Some are in clinical trial (phase II) for asthma or COPD (Table 2). TNF- $\alpha$ and TNFR antagonists include antibodies (infliximab, afelimomab, CytoTab, adalimumab, CDP-571, CDP-870), soluble TNFR (Onercept, Etanercept), small molecules (ISIS-104838), and inhibitors of TNF- $\alpha$-converting enzyme (TACE).

Recent studies have shown that treating patients with COPD with infliximab over 6 to 24 wk did not improve lung function, body weight, quality of life scores, airway inflammation, or cytokine levels (93-95). One study reported higher exhaled nitric oxide (NO) levels (93), whereas another study noted a tendency to improved 6-min walking distance (94). Subgroup analysis of COPD patients in different GOLD stages may reveal more details. In asthma, short-term treatment with etanercept enhanced TNFR p75 levels in the bronchial epithelial lining fluid but did not change airway eosinophilia or hyperresponsiveness (96). In a 10wk treatment study, Berry et al. (97) reported that etanercept improved the hyperresponsiveness by methacholine testing $\left(\mathrm{PC}_{20}\right)$ and $\mathrm{FEV}_{1}$ (postbronchodilator) as well as the quality of life scores as compared to treatment by placebo. However, no changes in inflammatory or total cell counts in sputum were noted.

TNF- $\alpha$ antagonists not only reduce inflammation but also tissue destruction by downregulation of MMP expression or inhibition of MMP activation $(98,99)$.
Mucin 5AC (MUC5AC) is an important constituent of mucus seen in chronic bronchitis. A potential therapeutic effect of infliximab was described by inhibiting the TNF- $\alpha$-induced expression of MUC5AC by an airway epithelial cell line (100). Other experimental TNF- $\alpha$ antagonists include the inhibitors of TACE such as Marimastat and BMS-561392 (Table 2). These molecules inhibit both pre-TNF- $\alpha$ cleavage into mature TNF- $\alpha$ and are inhibitors of MMPs. Recent studies demonstrated that cigarette smoke and lipopolysaccharide (LPS)-induced MUC5AC production in vitro via a TACE-dependent mechanism (101). Inhibition of TACE via TACE-specific drugs would appear to be potentially beneficial, especially in COPD/chronic bronchitis or asthma. However, side effects may include musculoskeletal pain, inflammatory polyarthritis, and hand contraction, potentially precluding its applicability (102). The concomitant inhibition of MMP activity may be important in restoration of the protease-antiprotease balance in COPD, which favors proteolytic breakdown of tissue at higher MMP and elastase activities. Among the preclinical drugs is TMI-1, a thiomorpholinecarboxamide derivative, which specifically inhibits LPS-induced TNF- $\alpha$ secretion, but not secretion of other proinflammatory cytokines such as IL-1 $\beta$, IL-6, or IL-8, both from human cell lines and in human explants (103). In vivo, TMI-1 reduced clinical symptoms in a collagen-induced arthritis model in mice (103).

Given the side effects, smaller noninjectable, bioactive molecules with long half-life and high bioavailability that are capable of regulating TNF- $\alpha$ expression, synthesis, and/or secretion seem to be needed (104). The antisense oligonucleotide for TNF- $\alpha$ (ISIS-104838) is an example of an orally available molecule in clinical trial for RA and Crohn's disease (Table 2). ISIS-104838 inhibits TNF- $\alpha$ mRNA translation into pre-TNF- $\alpha$ proteins, finally resulting in reduced extracellular TNF- $\alpha$ levels. Furthermore, TACE-specific siRNA, which blocks TACE mRNA synthesis, may prove to be useful, but little is known yet about the clinical effects. Inhalation antisense formulations are less likely to reduce systemic pulmonary inflammation in COPD, but may be useful in treating local pulmonary inflammation, and hence reduce tissue remodeling and mucus hyperproduction. In conclusion, given the selective efficacy of TNF- $\alpha$ antagonists, clinical trials for COPD with different antagonists other than infliximab seem worthwhile for determining efficacy.

\section{CHEMOKINES}

Macrophages migrate toward a gradient of CCL2, CCL3, or CCL4 via their receptors CCR2 or CCR5. Neutrophils are mainly attracted by CXCL1 and CXCL8 
via CXCR1 and CXCR2, of which CXCR1 has a larger affinity for CXCL8 than for CXCL1. CXCR1 is involved in neutrophilic degranulation, protease release, and oxidative stress. T-cells may have receptors for CCL2-4, and a subset also has CXCL10 receptors (CXCR3). In COPD, levels of some of these chemokines and their receptors may be associated with lung function (Table 1), and seem to be involved in the pathogenesis of COPD (60). As previously pointed out, chemokines seem to be involved in tissue repair processes $(18,61)$. Therefore, chemokine antagonists might have potential as specific treatments for both inflammation and tissue remodeling in COPD. A few of the many chemokine and chemokine receptor antagonists are in clinical trials for inflammatory diseases (Table 2) (60). These include an anti-CCR2 antibody (MLN1202) and small-molecule inhibitors INCB3284, SB332235, and SB656933 (60). For most drugs, no peer-reviewed data on effects on tissue remodeling have yet been published. However, RS-504393 - a preclinical CCR2 spiropiperidine antagonist-was shown to be capable of blocking CCR2-dependent renal fibrosis apart from reducing macrophage infiltration and activation and CCL2 expression in mice (105). Among the CXCL1 and CXCL8 antagonists that prevent binding to CXCR2, SB332235 and SB656933 are being evaluated in clinical trial phase I for COPD (Table 2). Whereas both drugs impair CXCR2-mediated effects on neutrophils, no data on human lung tissue remodeling or inflammation have yet been published for both drugs.

In contrast, SB225002 and SB265610 inhibit binding of CXCL1 and CXCL8 to CXCR2 by interfering with the chemokine binding sites (60). SB265610 treatment inhibited skin wound repair and neutrophil recruitment in a skin wound healing model in mice (61). Although inflammation can be reduced, a potential drawback of cytokine antagonists may be caused by the lung epithelial expression of functional chemokine receptors CCR2 and CXCR2, which are probably involved in epithelial migration and wound healing $(18,65)$. Inhibition of these receptors may impair wound healing following smoke exposure and hence, may increase the risk of infection and concomitant inflammation. In conclusion, chemokine antagonists may reduce pulmonary inflammation, but they may hamper epithelial repair upon smoke-induced damage. Further studies are needed to resolve this.

\section{TRANSCRIPTION FACTORS AND SIGNALING MOLECULES}

An alternative and recently explored route either to reduce growth factor, cytokine, or chemokine levels or to impair their effects is to interfere with gene expression or intracellular signal transduction. For growth factors, receptor tyrosine kinases are needed in order to activate downstream acting Ras, Raf, and MAPK p42 and p44 proteins. For cytokines and chemokines, signal transduction molecules such as NF- $\mathrm{kB}$ and MAPK p38 are needed. NF- $\mathrm{KB}$ is both a signal transduction and a transcription factor. In its inactive state, it is bound to another protein, Inhibitor of $\kappa B(\mathrm{I} \kappa \mathrm{B})$.

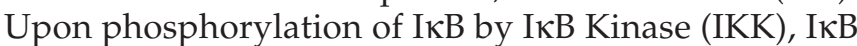
dissociates from the complex and becomes ubiquitinated and subsequently degraded. Then, activated $N F-\kappa B$ is translocated to the nucleus and binds to NF$\kappa \mathrm{B}$ binding sites in the promoter region of genes including cytokines, chemokines, and MMPs. MAPK p38 is activated via upstream signaling proteins including $G$ protein-coupled receptors. MAPK p38 is involved in the regulation of transcription factors and a variety of enzymes including those involved in histone remodeling (106). Studies have suggested that NF- $\mathrm{KB}$ and MAPK p38 are involved in the pathogenesis of COPD $(106,107)$. The therapeutic effects of antagonists may be achieved at the transcription level of these signaling molecules by blockade of intracellular translocation of NF- $\mathrm{kB}$, reduction of signaling of NF$\kappa \mathrm{B}$ by inhibition of I $\mathrm{KB}$ degradation, and inhibition of enzyme activity (108). Several antagonists of MAPK p38 (SB681323, RWJ67657, SCIO-469), NF-кB (siRNA), or IKK (BMS345541) are in preclinical or clinical trial phase I or II for inflammatory diseases including allergic rhinitis and COPD $(60,109)$. As MAPK p38 has four isozymes and each MAPK p38 inhibitor has its own specificity toward one or more of these isozymes, this specificity may cause differential effects. With respect to NF- $\kappa \mathrm{B}$, several studies have indicated the involvement of NF- $\mathrm{KB}$ in tissue remodeling. Using an in vivo model for intestinal disease, Lawrance et al. (110) reported that treatment of mice with antisense NF- $\kappa B$ p65 reduced the intestinal fibrosis.

In rat tracheal explants, the NF- $\mathrm{BB}$ inhibitor SN50 inhibited both TGF- $\beta 1$ and procollagen I expression that was enhanced by exposure to diesel exhaust particles

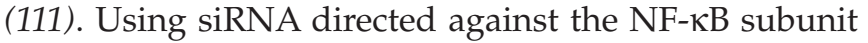
p65 in airway epithelial cell lines caused an impaired TNF- $\alpha$-induced NF- $\kappa B$ p65, IL-6, and CXCL8 expression (112). Hence, NF- $\kappa B$ inhibitors may potently reduce not only inflammation but also matrix remodeling in chronic inflammatory disease like COPD. An antisense antagonist for NF- $\mathrm{KB}$ p65 is now in clinical trial phase I for Crohn's disease .

Another class of kinases regulate activation of signaling proteins. The biaryl-urea-derivate BAY 43-9006 is a dual inhibitor of Raf kinase and VEGFR being tested in clinical phase III studies for treatment of cancer $(113,114)$. This drug impairs tumor growth and angiogenesis. Recently, Hewson et al. (115) showed that MUC5AC expression by airway epithelial cells needed 
Ras and Raf activation downstream from EGFR activation. Hence, BAY 43-9006 may potentially reduce growth factor receptor tyrosine kinase-induced proliferation or MUC5AC expression as well as vascular remodeling as seen in COPD.

TGF- $\beta R$ signal transduction involves the downstream-acting Smad transcription factors. This pathway includes Smad2 and Smad3, which activate TGF- $\beta$ responsive genes, and the inhibitory Smad6 and Smad7 proteins (116). Patients with COPD were observed to have an unchanged Smad3 expression in the airways, whereas expression of Smad6 and 7 was lower as compared to patients without COPD (117). In addition, cigarette smoke extract reduced the Smad6 and Smad7 expression in alveolar epithelial A549 cells in vitro (117). SB431542 and the more potent SB505124 inhibit Smad2 and 3 phosphorylation, their nuclear translocation, and TGF- $\beta$-induced collagen I synthesis and tumor cell death $(117,118)$. These data point to the potential use of Smad2/3 antagonists or Smad6/7 agonists in the treatment of airway remodeling in COPD.

In conclusion, several inhibitors of MAPK p38 and $\mathrm{NF}-\mathrm{\kappa B}$ are at a more advanced stage with respect to clinical trials, whereas antagonists for Raf, IKK, and Smad2/3 may also prove to be useful for therapy against remodeling and inflammation. The potential disadvantage of using inhibitors of cell signaling molecules is that these molecules are general signal transduction proteins involved in various physiological processes. Systemic administration of antagonists may have profound effects on other receptor-mediated pathways other than the pro-inflammatory and remodeling reactions in COPD. Moreover, inhibition of these molecules may also potentially impair defense and repair mechanisms resulting in increased infection risk.

\section{PERSPECTIVES AND CONCLUDING REMARKS}

Although imbalance mechanisms between proteases and antiproteases and oxidants and antioxidants are thought to prevail in COPD, pathogenetic mechanisms with regard to tissue remodeling are not yet clarified. Changes in ECM, epithelial metaplasia in chronic bronchitis and asthmatics or apoptosis in emphysema, and vascular changes can occur. Recent investigations also point to the potential molecules involved in these processes, including growth factors and cyto- or chemokines. Specific antagonist drugs capable of reducing growth factor and cytokine expression or signaling are available or being tested. Some seem to be effective in different inflammatory diseases or in reducing tumor growth. However, these antagonists have not yet been tested extensively with regard to reducing the remodel- ing processes in chronic inflammatory lung diseases. Experimental models and expression studies suggest that anti-VEGFR strategies may be of use in patients with emphysema, whereas anti-HER1 directed strategies may be more useful in patients with pulmonary mucus hypersecretion as seen in chronic bronchitis and asthma. This suggests the need of stratification of antagonist therapy. However, a complete block of cytokinedriven or growth factor-dependent repair mechanisms may be disadvantageous, as defense reactions to infection may be impaired. Antibiotics may overcome bacterial infection but are not useful as a strategy for treating viral infections. The efficacy and bioavailablity of biological drugs may be improved by reducing immunogenicity and improving routes of administration. Finally, restoration of lung tissue structure may be provided by other drugs such as retinoic acids. Such approaches, however, must await the first results of growth factor or cytokine antagonist therapy in chronic lung diseases.

\section{REFERENCES}

1. Celli, B. R. and MacNee, W. (2004) Standards for the diagnosis and treatment of patients with COPD: a summary of the ATS/ERS position paper. Eur. Respir. J. 23, 932-946.

2. Pauwels, R. A. and Rabe, K. F. (2004) Burden and clinical features of chronic obstructive pulmonary disease (COPD). Lancet 364, 613-620.

3. GOLD (updated 2005) Global Initiative for Chronic Obstructive Lung Disease. Global strategy for the diagnosis, management, and prevention of chronic obstructive pulmonary disease.

4. Silva, G. E., Sherrill, D. L., Guerra, S., and Barbee, R. A. (2004) Asthma as a risk factor for COPD in a longitudinal study. Chest 126, 59-65.

5. DeMeo, D. L. and Silverman, E. K. (2003) Genetics of chronic obstructive pulmonary disease. Semin. Respir. Crit. Care. Med. 24, 151-160.

6. Sakao, S., Tatsumi, K., Igari, H., et al. (2002) Association of tumor necrosis factor-alpha gene promoter polymorphism with low attenuation areas on high-resolution CT in patients with COPD. Chest 122, 416-420.

7. He, J. Q., Ruan, J., Connett, J. E., Anthonisen, N. R., Pare, P. D., and Sandford, A. J. (2002) Antioxidant gene polymorphisms and susceptibility to a rapid decline in lung function in smokers. Am. J. Respir. Crit. Care Med. 166, 323-328.

8. Joos, L., He, J. Q., Shepherdson, M. B., et al. (2002) The role of matrix metalloproteinase polymorphisms in the rate of decline in lung function. Hum. Mol. Genet. 11, 569-576.

9. Molfino, N. A. (2004) Genetics of COPD. Chest 125, 1929-1940.

10. Jeffery, P. K. (2004) Remodeling and inflammation of bronchi in asthma and chronic obstructive pulmonary disease. Proc. Am. Thorac. Soc. 1, 176-183. 
11. Agusti, A. G., Noguera, A., Sauleda, J., Sala, E., Pons, J., and Busquets, X. (2003) Systemic effects of chronic obstructive pulmonary disease. Eur. Respir. J. 21, 347-360.

12. Langen, R.C., Korn, S. H., and Wouters, E. F. (2003) ROS in the local and systemic pathogenesis of COPD. Free Radic. Biol. Med. 35, 226-235.

13. Gan, W. Q., Man, S. F., Senthilselvan, A., and Sin, D. D. (2004) Association between chronic obstructive pulmonary disease and systemic inflammation: a systematic review and a meta-analysis. Thorax 59, 574-580.

14. Hogg, J. C. (2004) Pathophysiology of airflow limitation in chronic obstructive pulmonary disease. Lancet 364, 709-721.

15. Kranenburg, A. R., De Boer, W. I., Van Krieken, J. H., et al. (2002) Enhanced expression of fibroblast growth factors and receptor FGFR-1 during vascular remodeling in chronic obstructive pulmonary disease. Am. J. Respir. Cell Mol. Biol. 27, 517-525.

16. Barnes, P.J., Shapiro, S. D., and Pauwels, R. A. (2003) Chronic obstructive pulmonary disease: molecular and cellular mechanisms. Eur. Respir. J. 22, 672-688.

17. Vachier, I., Vignola, A. M., Chiappara, G., et al. (2004) Inflammatory features of nasal mucosa in smokers with and without COPD. Thorax 59, 303-307.

18. De Boer, W. I. (2002) Cytokines and therapy in COPD: a promising combination? Chest 121, 209S-218S.

19. Cosio, M., Ghezzo, H., Hogg, J. C., et al. (1978) The relations between structural changes in small airways and pulmonary-function tests. N. Engl. J. Med. 298, 1277-1281.

20. Willemse, B. W., Postma, D. S., Timens, W., and ten Hacken, N. H. (2004) The impact of smoking cessation on respiratory symptoms, lung function, airway hyperresponsiveness and inflammation. Eur. Respir. J. 23, 464-476.

21. Smith, C. A. and Harrison, D. J. (1997) Association between polymorphism in gene for microsomal epoxide hydrolase and susceptibility to emphysema. Lancet 350 , 630-633.

22. Papi, A., Bellettato, C. M., Braccioni, F., et al. (2006) Infections and airway inflammation in chronic obstructive pulmonary disease severe exacerbations. Am. J. Respir. Crit. Care Med. 173, 1114-1121.

23. Seemungal, T. A. and Wedzicha, J. A. (2003) Viral infections in obstructive airway diseases. Curr. Opin. Pulm. Med. 9, 111-116.

24. de Boer, W. I., Hau, C. M., van Schadewijk, A., Stolk, J., van Krieken, J. H., and Hiemstra, P. S. (2006) Expression of epidermal growth factors and their receptors in the bronchial epithelium of subjects with chronic obstructive pulmonary disease. Am. J. Clin. Pathol. 125, 184-192.

25. Burgel, P. R. and Nadel, J. A. (2004) Roles of epidermal growth factor receptor activation in epithelial cell repair and mucin production in airway epithelium. Thorax 59, 992-996.

26. Puddicombe, S. M., Polosa, R., Richter, A., et al. (2000) Involvement of the epidermal growth factor receptor in epithelial repair in asthma. FASEB J. 14, 1362-1374.

27. Polosa, R., Puddicombe, S. M., Krishna, M. T., et al. (2002) Expression of c-erbB receptors and ligands in the bronchial epithelium of asthmatic subjects. J. Allergy Clin. Immunol. 109, 75-81.

28. Vignola, A. M., Chanez, P., Chiappara, G., et al. (1997) Transforming growth factor-beta expression in mucosal biopsies in asthma and chronic bronchitis. Am. J. Respir. Crit. Care Med. 156, 591-599.

29. Mohammadi, M., Olsen, S. K., and Ibrahimi, O. A. (2005) Structural basis for fibroblast growth factor receptor activation. Cytokine Growth Factor Rev. 16, 107-137.

30. Finch, P. W. and Rubin, J. S. (2004) Keratinocyte growth factor/fibroblast growth factor 7, a homeostatic factor with therapeutic potential for epithelial protection and repair. Adv. Cancer Res. 91, 69-136.

31. Braun, S., auf dem Keller, U., Steiling, H., and Werner, S. (2004) Fibroblast growth factors in epithelial repair and cytoprotection. Philos. Trans. R. Soc. Lond. B Biol. Sci. 359, 753-757.

32. Kranenburg, A. R., Willems-Widyastuti, A., Mooi, W. J., et al. (2005) Chronic obstructive pulmonary disease is associated with enhanced bronchial expression of FGF-1, FGF-2, and FGFR-1. J. Pathol. 206, 28-38.

33. Shute, J. K., Solic, N., Shimizu, J., McConnell, W., Redington, A. E., and Howarth, P. H. (2004) Epithelial expression and release of FGF-2 from heparan sulphate binding sites in bronchial tissue in asthma. Thorax 59, 557-562.

34. Hoshino, M., Nakamura, Y., and Hamid, Q. A. (2001) Gene expression of vascular endothelial growth factor and its receptors and angiogenesis in bronchial asthma. J. Allergy Clin. Immunol. 107, 1034-1038.

35. Kranenburg, A. R., de Boer, W. I., Alagappan, V. K., Sterk, P. J., and Sharma, H. S. (2005) Enhanced bronchial expression of vascular endothelial growth factor and receptors (Flk-1 and Flt-1) in patients with chronic obstructive pulmonary disease. Thorax 60, 106-113.

36. Kasahara, Y., Tuder, R. M., Cool, C. D., Lynch, D. A., Flores, S. C., and Voelkel, N. F. (2001) Endothelial cell death and decreased expression of vascular endothelial growth factor and vascular endothelial growth factor receptor 2 in emphysema. Am. J. Respir. Crit. Care Med. 163, 737-744.

37. Santos, S., Peinado, V. I., Ramirez, J., et al. (2003) Enhanced expression of vascular endothelial growth factor in pulmonary arteries of smokers and patients with moderate chronic obstructive pulmonary disease. Am. J. Respir. Crit. Care Med. 167, 1250-1256.

38. Le Cras, T. D., Spitzmiller, R. E., Albertine, K. H., Greenberg, J. M., Whitsett, J. A., and Akeson, A. L. (2004) VEGF causes pulmonary hemorrhage, hemosiderosis, and air space enlargement in neonatal mice. Am. J. Physiol. Lung Cell Mol. Physiol. 287, L134-L142.

39. Tsao, P. N., Su, Y. N., Li, H., et al. (2004) Overexpression of placenta growth factor contributes to the pathogenesis of pulmonary emphysema. Am. J. Respir. Crit. Care Med. 169, 505-511.

40. Tang, K., Rossiter, H. B., Wagner, P. D., and Breen, E. C. (2004) Lung-targeted VEGF inactivation leads to an emphysema phenotype in mice. J. Appl. Physiol. 97, 1559-1566; discussion 1549. 
41. Kearney, J. B., Ambler, C. A., Monaco, K. A., Johnson, N., Rapoport, R. G., and Bautch, V. L. (2002) Vascular endothelial growth factor receptor Flt-1 negatively regulates developmental blood vessel formation by modulating endothelial cell division. Blood 99, 2397-2407.

42. Rahimi, N., Dayanir, V., and Lashkari, K. (2000) Receptor chimeras indicate that the vascular endothelial growth factor receptor-1 (VEGFR-1) modulates mitogenic activity of VEGFR-2 in endothelial cells. J. Biol. Chem. 275, $16,986-16,992$.

43. Rafii, S., Avecilla, S., Shmelkov, S., et al. (2003) Angiogenic factors reconstitute hematopoiesis by recruiting stem cells from bone marrow microenvironment. Ann. $N$ Y Acad. Sci. 996, 49-60.

44. Santos, S., Peinado, V. I., Ramirez, J., et al. (2002) Characterization of pulmonary vascular remodelling in smokers and patients with mild COPD. Eur. Respir. J. 19, 632-638.

45. Kasahara, Y., Tuder, R. M., Taraseviciene-Stewart, L., et al. (2000) Inhibition of VEGF receptors causes lung cell apoptosis and emphysema. J. Clin. Invest. 106, 1311-1319.

46. Bonniaud, P., Kolb, M., Galt, T., et al. (2004) Smad3 null mice develop airspace enlargement and are resistant to TGF-beta-mediated pulmonary fibrosis. J. Immunol. 173, 2099-2108.

47. de Boer, W.I., van Schadewijk, A., Sont, J. K., et al. (1998) Transforming growth factor beta1 and recruitment of macrophages and mast cells in airways in chronic obstructive pulmonary disease. Am. J. Respir. Crit. Care Med. 158, 1951-1957.

48. Takizawa, H., Tanaka, M., Takami, K., et al. (2001) Increased expression of transforming growth factor-beta1 in small airway epithelium from tobacco smokers and patients with chronic obstructive pulmonary disease (COPD). Am. J. Respir. Crit. Care Med. 163, 1476-1483.

49. Ning, W., Li, C. J., Kaminski, N., et al. (2004) Comprehensive gene expression profiles reveal pathways related to the pathogenesis of chronic obstructive pulmonary disease. Proc. Natl. Acad. Sci. USA 101, 14,895-14,900.

50. Baraldo, S., Bazzan, E., Turato, G., et al. (2005) Decreased expression of TGF-beta type II receptor in bronchial glands of smokers with COPD. Thorax 60, 998-1002.

51. Johnson, P. R., Black, J. L., Carlin, S., Ge, Q., and Underwood, P. A. (2000) The production of extracellular matrix proteins by human passively sensitized airway smooth-muscle cells in culture: the effect of beclomethasone. Am. J. Respir. Crit. Care Med. 162, 2145-2151.

52. Kranenburg, A. R., Willems-Widyastuti, A., Saxena, P. R., Sterk, P. J., de Boer, W. I., and Sharma, H. S. (2002) Enhanced pulmonary expression of extracellular matrix proteins in central airways of COPD patients. Am. J. Respir. Crit. Care Med. 165, A600.

53. Howarth, P. H., Knox, A. J., Amrani, Y., et al. (2004) Synthetic responses in airway smooth muscle. J. Allergy Clin. Immunol. 114, S32-S50.

54. Foda, H. D., George, S., Rollo, E., et al. (1999) Regulation of gelatinases in human airway smooth muscle cells: mechanism of progelatinase A activation. Am. J. Physiol. 277, L174-L182.
55. Parameswaran, K., Willems-Widyastuti, A., Alagappan, V. K. T., Radford, K., Kranenburg, A. R., and Sharma, H. S. (2006) Role of extra cellular matrix and its regulators in human airway smooth muscle biology. Cell Biochem. Biophys. 44, 139-146.

56. Elshaw, S. R., Henderson, N., Knox, A. J., Watson, S. A., Buttle, D. J., and Johnson, S. R. (2004) Matrix metalloproteinase expression and activity in human airway smooth muscle cells. Br. J. Pharmacol. 142, 1318-1324.

57. McKay, S., de Jongste, J. C., Saxena, P. R., and Sharma, H. S. (1998) Angiotensin II induces hypertrophy of human airway smooth muscle cells: expression of transcription factors and transforming growth factor-beta1. Am. J. Respir. Cell Mol. Biol. 18, 823-833.

58. Burgess, J. K., Johnson, P. R., Ge, Q., et al. (2003) Expression of connective tissue growth factor in asthmatic airway smooth muscle cells. Am. J. Respir. Crit. Care Med. 167, 71-77.

59. de Boer, W. I. (2003) Potential new drugs for therapy of chronic obstructive pulmonary disease. Expert Opin. Investig. Drugs. 12, 1067-1086.

60. de Boer, W. I. (2005) Perspectives for cytokine antagonist therapy in COPD. Drug Discov.. Today 10, 93-106.

61. Milatovic, S., Nanney, L. B., Yu, Y., White, J. R., and Richmond, A. (2003) Impaired healing of nitrogen mustard wounds in CXCR2 null mice. Wound Repair Regen. 11, 213-219.

62. Rennekampff, H. O., Hansbrough, J. F., Kiessig, V., Dore, C., Sticherling, M., and Schroder, J. M. (2000) Bioactive interleukin-8 is expressed in wounds and enhances wound healing. J. Surg. Res. 93, 41-54.

63. Heinrich, S. A., Messingham, K. A., Gregory, M. S., et al. (2003) Elevated monocyte chemoattractant protein-1 levels following thermal injury precede monocyte recruitment to the wound site and are controlled, in part, by tumor necrosis factor-alpha. Wound Repair Regen. 11, 110-119.

64. Lundien, M. C., Mohammed, K. A., Nasreen, N., et al. (2002) Induction of MCP-1 expression in airway epithelial cells: role of CCR2 receptor in airway epithelial injury. J. Clin. Immunol. 22, 144-152.

65. Christensen, P. J., Du, M., Moore, B., Morris, S., Toews, G. B., and Paine, R., 3rd (2004) Expression and functional implications of CCR2 expression on murine alveolar epithelial cells. Am. J. Physiol. Lung Cell Mol. Physiol. 286, L68-L72.

66. Gharaee-Kermani, M., Denholm, E. M., and Phan, S. H. (1996) Costimulation of fibroblast collagen and transforming growth factor beta1 gene expression by monocyte chemoattractant protein-1 via specific receptors. $J$. Biol. Chem. 271, 17,779-17,784.

67. Cheng, J., Diaz Encarnacion, M. M., Warner, G. M., Gray, C. E., Nath, K. A., and Grande, J. P. (2005) TGF-beta1 stimulates monocyte chemoattractant protein-1 expression in mesangial cells through a phosphodiesterase isoenzyme 4-dependent process. Am. J. Physiol. Cell Physiol. 289, C959-C970.

68. Sutherland, E. R. and Cherniack, R. M. (2004) Management of chronic obstructive pulmonary disease. N. Engl. J. Med. 350, 2689-2697. 
69. Calverley, P., Pauwels, R., Vestbo, J., et al. (2003) Combined salmeterol and fluticasone in the treatment of chronic obstructive pulmonary disease: a randomised controlled trial. Lancet 361, 449-456.

70. Donnelly, L. E. and Rogers, D. F. (2003) Therapy for chronic obstructive pulmonary disease in the 21st century. Drugs 63, 1973-1998.

71. Barnes, P. J. and Hansel, T. T. (2004) Prospects for new drugs for chronic obstructive pulmonary disease. Lancet 364, 985-996.

72. O'Donnell, R. A., Richter, A., Ward, J., et al. (2004) Expression of ErbB receptors and mucins in the airways of long term current smokers. Thorax 59, 1032-1040.

73. Crombet, T., Osorio, M., Cruz, T., et al. (2004) Use of the humanized anti-epidermal growth factor receptor monoclonal antibody h-R3 in combination with radiotherapy in the treatment of locally advanced head and neck cancer patients. J. Clin. Oncol. 22, 1646-1654.

74. Albanell, J., Codony, J., Rovira, A., Mellado, B., and Gascon, P. (2003) Mechanism of action of anti-HER2 monoclonal antibodies: scientific update on trastuzumab and 2C4. Adv. Exp. Med. Biol. 532, 253-268.

75. Cohen, M. H., Williams, G. A., Sridhara, R., et al. (2004) United States Food and Drug Administration Drug Approval summary: Gefitinib (ZD1839; Iressa) tablets. Clin. Cancer Res. 10, 1212-1218.

76. Chang, G. C., Hsu, S. L., Tsai, J. R., et al. (2004) Molecular mechanisms of ZD1839-induced G1-cell cycle arrest and apoptosis in human lung adenocarcinoma A549 cells. Biochem. Pharmacol. 68, 1453-1464.

77. Kedar, D., Baker, C. H., Killion, J. J., Dinney, C. P., and Fidler, I. J. (2002) Blockade of the epidermal growth factor receptor signaling inhibits angiogenesis leading to regression of human renal cell carcinoma growing orthotopically in nude mice. Clin. Cancer Res. 8, 3592-3600.

78. Lee, C. G., Link, H., Baluk, P., et al. (2004) Vascular endothelial growth factor (VEGF) induces remodeling and enhances TH2-mediated sensitization and inflammation in the lung. Nat. Med. 10, 1095-1103.

79. Ferrara, N., Gerber, H.P ., and LeCouter, J. (2003) The biology of VEGF and its receptors. Nat. Med. 9, 669-676.

80. Sandler, A. B., Johnson, D. H., and Herbst, R. S. (2004) Antivascular endothelial growth factor monoclonals in nonsmall cell lung cancer. Clin. Cancer Res. 10, 4258s-4262s.

81. Cursiefen, C., Chen, L., Borges, L. P., et al. (2004) VEGF-A stimulates lymphangiogenesis and hemangiogenesis in inflammatory neovascularization via macrophage recruitment. J. Clin. Invest. 113, 1040-1050.

82. Underiner, T. L., Ruggeri, B., and Gingrich, D. E. (2004) Development of vascular endothelial growth factor receptor (VEGFR) kinase inhibitors as anti-angiogenic agents in cancer therapy. Curr. Med. Chem. 11, 731-745.

83. Ton, N. C. and Jayson, G. C. (2004) Resistance to antiVEGF agents. Curr. Pharm. Des. 10, 51-64.

84. Voelkel, N. F. and Cool, C. D. (2003) Pulmonary vascular involvement in chronic obstructive pulmonary disease. Eur. Respir. J. Suppl. 46, 28s-32s.

85. Thannickal, V. J., Aldweib, K. D., Rajan, T., and Fanburg, B. L. (1998) Upregulated expression of fibroblast growth factor (FGF) receptors by transforming growth factorbeta1 (TGF-beta1) mediates enhanced mitogenic responses to FGFs in cultured human lung fibroblasts. Biochem. Biophys. Res. Commun. 251, 437-441.

86. Arias, M., Sauer-Lehnen, S., Treptau, J., et al. (2003) Adenoviral expression of a transforming growth factorbeta1 antisense mRNA is effective in preventing liver fibrosis in bile-duct ligated rats. BMC Gastroenterol. 3, 29.

87. Yang, Y. A., Dukhanina, O., Tang, B., et al. (2002) Lifetime exposure to a soluble TGF-beta antagonist protects mice against metastasis without adverse side effects. J. Clin. Invest. 109, 1607-1615.

88. Liu, M., Suga, M., Maclean, A. A., St George, J. A., Souza, D. W., and Keshavjee, S. (2002) Soluble transforming growth factor-beta type III receptor gene transfection inhibits fibrous airway obliteration in a rat model of Bronchiolitis obliterans. Am. J. Respir. Crit. Care Med. 165, 419-423.

89. Lutgens, E., Gijbels, M., Smook, M., et al. (2002) Transforming growth factor-beta mediates balance between inflammation and fibrosis during plaque progression. Arterioscler. Thromb. Vasc. Biol. 22, 975-982.

90. Kucukaycan, M., Van Krugten, M., Pennings, H. J., et al. (2002) Tumor Necrosis Factor-alpha +489 G/A gene polymorphism is associated with chronic obstructive pulmonary disease. Respir. Res. 3, 29.

91. Churg, A., Dai, J., Tai, H., Xie, C., and Wright, J. L. (2002) Tumor necrosis factor-alpha is central to acute cigarette smoke-induced inflammation and connective tissue breakdown. Am. J. Respir. Crit. Care Med. 166, 849-854.

92. Churg, A., Wang, R. D., Tai, H., Wang, X., Xie, C., and Wright, J. L. (2004) Tumor necrosis factor-alpha drives $70 \%$ of cigarette smoke-induced emphysema in the mouse. Am. J. Respir. Crit. Care Med. 170, 492-498.

93. van der Vaart, H., Koeter, G. H., Postma, D. S., Kauffman, H. F., and ten Hacken, N. H. (2005) First study of infliximab treatment in patients with chronic obstructive pulmonary disease. Am. J. Respir. Crit. Care Med. 172, 465-469.

94. Abdelhady, H., Flores, R., Tan, H., Hasday, J., Fitzgerald, T., and Scharf, S. M. (2005) Infliximab treatment for chronic obstructive pulmonary disease (COPD) - a pilot study. Am. J. Respir. Crit. Care Med. 171(Suppl), A133.

95. Rennard, S. I. (2005) Secondary analyses of the phase II, dose finding study evaluating safety and efficacy of infliximab in patients with moderate to severe chronic obstructive pulmonary disease. Am. J. Respir. Crit. Care Med. 171 Suppl, A133.

96. Rouhani, F. N., Meitin, C. A., Kaler, M., MiskinisHilligoss, D., Stylianou, M., and Levine, S. J. (2005) Effect of tumor necrosis factor antagonism on allergen-mediated asthmatic airway inflammation. Respir. Med. 99, 1175-1182.

97. Berry, M. A., Hargadon, B., Shelley, M., et al. (2006) Evidence of a role of tumor necrosis factor alpha in refractory asthma. N. Engl. J. Med. 354, 697-708.

98. Kobayashi, M., Squires, G. R., Mousa, A., et al. (2005) Role of interleukin-1 and tumor necrosis factor alpha in matrix degradation of human osteoarthritic cartilage. Arthritis Rheum. 52, 128-135. 
99. Klinkhoff, A. (2004) Biological agents for rheumatoid arthritis: targeting both physical function and structural damage. Drugs 64, 1267-1283.

100. Mand, C., Henke, M. O., Song, X. Y., and Rubin, B. K. (2004) Infliximab inhibits TNFa-induced MUC5AC and MUC5B mucin secretion in differentiated airway cells. Proc. Am. Thor. Soc. 1, A540.

101. Shao, M. X., Nakanaga, T., and Nadel, J. A. (2004) Cigarette smoke induces MUC5AC mucin overproduction via tumor necrosis factor-alpha-converting enzyme in human airway epithelial (NCI-H292) cells. Am. J. Physiol. Lung Cell Mol. Physiol. 287, L420-L427.

102. Daheshia, M. (2005) Therapeutic inhibition of matrix metalloproteinases for the treatment of chronic obstructive pulmonary disease (COPD). Curr. Med. Res. Opin. 21, 587-594.

103. Zhang, Y., Xu, J., Levin, J., et al. (2004) Identification and characterization of 4-[[4-(2-butynyloxy)phenyl]sulfonyl]N-hydroxy-2,2-dimethyl-(3S)thiomorpho linecarboxamide (TMI-1), a novel dual tumor necrosis factor-alpha-converting enzyme/matrix metalloprotease inhibitor for the treatment of rheumatoid arthritis. J. Pharmacol. Exp. Ther. 309, 348-355.

104. Palladino, M. A., Bahjat, F. R., Theodorakis, E. A., and Moldawer, L. L. (2003) Anti-TNF-alpha therapies: the next generation. Nat. Rev. Drug Discov. 2, 736-746.

105. Kitagawa, K., Wada, T., Furuichi, K., et al. (2004) Blockade of CCR2 ameliorates progressive fibrosis in kidney. Am. J. Pathol. 165, 237-246.

106. Rahman, I. (2003) Oxidative stress, chromatin remodeling and gene transcription in inflammation and chronic lung diseases. J. Biochem. Mol. Biol. 36, 95-109.

107. Wright, J. G. and Christman, J. W. (2003) The role of nuclear factor kappa B in the pathogenesis of pulmonary diseases: implications for therapy. Am. J. Respir. Med. 2, 211-219.

108. Gorska, M. M. and Alam, R. (2003) Signaling molecules as therapeutic targets in allergic diseases. J. Allergy Clin. Immunol. 112, 241-250; quiz 251.
109. Karin, M., Yamamoto, Y., and Wang, Q. M. (2004) The IKK NF-kappa B system: a treasure trove for drug development. Nat. Rev. Drug Discov. 3, 17-26.

110. Lawrance, I. C., Wu, F., Leite, A. Z., et al. (2003) A murine model of chronic inflammation-induced intestinal fibrosis down-regulated by antisense NF-kappa B. Gastroenterology 125, 1750-1761.

111. Dai, J., Xie, C., Vincent, R., and Churg, A. (2003) Air pollution particles produce airway wall remodeling in rat tracheal explants. Am. J. Respir. Cell Mol. Biol. 29, 352-358.

112. Platz, J., Pinkenburg, O., Beisswenger, C., Puchner, A., Damm, T., and Bals, R. (2005) Application of small interfering RNA (siRNA) for modulation of airway epithelial gene expression. Oligonucleotides 15, 132-138.

113. Sebolt-Leopold, J. S. and English, J. M. (2006) Mechanisms of drug inhibition of signalling molecules. Nature 441, 457-462.

114. Wilhelm, S. M., Carter, C., Tang, L., et al. (2004) BAY 439006 exhibits broad spectrum oral antitumor activity and targets the RAF/MEK/ERK pathway and receptor tyrosine kinases involved in tumor progression and angiogenesis. Cancer Res. 64, 7099-7109.

115. Hewson, C. A., Edbrooke, M. R., and Johnston, S. L. (2004) PMA induces the MUC5AC respiratory mucin in human bronchial epithelial cells, via PKC, EGF/TGF-alpha, Ras/Raf, MEK, ERK and Sp1-dependent mechanisms. J. Mol. Biol. 344, 683-695.

116. Groneberg, D. A., Witt, H., Adcock, I. M., Hansen, G., and Springer, J. (2004) Smads as intracellular mediators of airway inflammation. Exp. Lung Res. 30, 223-250.

117. Springer, J., Scholz, F. R., Peiser, C., Groneberg, D. A., and Fischer, A. (2004) SMAD-signaling in chronic obstructive pulmonary disease: transcriptional down-regulation of inhibitory SMAD 6 and 7 by cigarette smoke. Biol. Chem. 385, 649-653.

118. DaCosta Byfield, S., Major, C., Laping, N. J., and Roberts, A. B. (2004) SB-505124 is a selective inhibitor of transforming growth factor-beta type I receptors ALK4, ALK5, and ALK7. Mol. Pharmacol. 65, 744-752. 